\title{
THE RIGHT TO COUNSEL DURING POLICE INTERROGATION: THE AFTERMATH OF ESCOBEDO
}

At the close of the 1963 term, the United States Supreme Court decided two cases involving the relationship between police interrogation of a suspected criminal offender and the sixth amendment right to counsel. In Massiah v. United States, ${ }^{1}$ it was held that, once indicted, the defendant is entitled to the assistance of counsel, and that incriminating statements elicited from the accused during this period may not be admitted into evidence; subsequently, the Court held in Escobedo $v$. Illinois ${ }^{2}$ that the accused may not be denied the assistance of counsel during the interrogation stage of a police investigation, even though lie has not yet been formally charged.

The sixth amendment to the Federal Constitution provides: "In all criminal prosecutions the accused shall enjoy the right ... to liave the assistance of Counsel for his defense." It is a source of protection to the accused in Federal, and, through the fourteenth amendment, state proceedings as well. ${ }^{4}$ Prior to its decisions in Massiah and Escobedo, the Court had extended the right to counsel beyond the trial stage, ${ }^{5}$ to the arraignment proceeding ${ }^{6}$ and the preliminary liearing. ${ }^{7}$ Extending the riglit to counsel to police interrogations is certain to have far-reaching effects. This Comment will assess its potential impact on police investigatory procedures and on law enforcement and to suggest the course of future development of the constitutional principles governing interrogation of those accused of crime. This will require an examination of the factual setting in both Massiah and Escobedo, an analysis in detail of the particular elements of the Escobedo decision, with particular at-

1377 U.S. 201 (1964).

2378 U.S. 478 (1964). Justice Goldberg wrote the majority opinion in which he was joined by Chief Justice Warren, and Justices Black, Douglas, and Brennan. Justices Harlan, White, and Stewart each wrote dissenting opinions in which they expressed concern for the implications of this opinion and the impact it might have upon law enforcement.

3 U.S. CoNst. amend. VI.

4 Gideon v. Wainwright, 372 U.S. 335 (1963). Until Gideon, the Court had always held that the sixth amendment right to counsel applied only in the Federal courts. Only where the presence of "special circumstances" indicated prejudice to the defendant was the denial of counsel in a State court proceeding considered to be a denial of due process of law as guaranteed by the fourteenth amendment. Betts v. Brady, 316 U.S. 455 (1942).

5 Johnson v. Zerbst, 304 U.S. 458 (1938). FED. R. CRax. P. 44 now requires that "If the defendant appears in court without counsel, the court shall advise him of his right to counsel and assign counsel to represent him at every stage of the proceeding unless he elects to proceed without counsel or is able to obtain counsel."

6 Walker v. Johnston, 312 U.S. 275 (1941); Von Moltke v. Gillies, 332 U.S. 708 (1948).

7 White v. Maryland, 373 U.S. 59 (1963). But see State v. Kïrkland, 82 N.J. Super. 409,197 A.2d 876 (1964) (counsel need not be provided if the preliminary hearing isn't "critical"). 
tention given to the constitutional privilege against self-incrimination, and an attempt to define the boundaries of the right to counsel during the police interrogation stage of a "criminal prosecution."

\section{I}

\section{Massiah and Escobedo-FACTS AND HOLDINGS}

In Massiah, the defendant had originally been indicted for violating the Federal narcotics laws. He had pleaded not guilty and had been released on bail. Unknown to him, the police had succeeded in enlisting the assistance of one of his accomplices. By means of a radio transmitter placed in the accomphice's car, a government agent was able to overhear a conversation between the accomplice and Massiah, in which the latter made certain incriminating admissions. ${ }^{8}$ Testimony of the agent as to these statements was admitted at Massiah's trial, over the objections of his attorney. The Supreme Court reversed the conviction ${ }^{0}$ on the ground that the actions of the government had been in reality a surreptitious interrogation in which the accused had been denied the assistance of counsel in violation of the sixth amendment.

One month later, the Court decided Escobedo v. Illinois and extended the right to counsel into the interrogation room itself. Danny Escobedo had been arrested and brought to the police station for questioning about the murder of his brother-in-law. The police rejected repeated requests by the accused to see his attorney, who was waiting in the next room, and did not warn Escobedo of his right to remain silent. After several hours of interrogation Escobedo made certain admissions which implicated him in a plot to commit murder. He was convicted of first degree murder on the strength of his confession. ${ }^{10}$ The Supreme Court of the United States granted certiorari ${ }^{11}$ and reversed. The Court purported to himit its holding to the facts of the case:

We hold, therefore, that where, as here, the investigation is no longer

8 The Court did not purport to consider the fourth amendment issue. 377 U.S. at 204. See On Lee v. United States, 343 U.S. 747 (1952); Lopez v. United States, 373 U.S. 427 (1963) (Warren, C.J., concurring).

${ }^{8}$ The Second Circuit had reversed in part and affirmed in part. $307 \mathrm{~F} .2 \mathrm{~d} 62$ (2d Cir. 1962).

10 On appeal to the Suprenie Court of Illinois the judgment was reversed, on the ground that the evidence indicated that the statements had been made as a result of a promise of imnumity. People v. Escobedo, No. 36707, IIl. Sup. Ct., February 1, 1963. On rehearing, the conviction was confirmed, the Court refusing to disturb the trial court's finding that the confession was voluntary. The Court also held that a denial of counsel during interrogation was not alone a denial of due process. People v. Escobedo, 28 Ill. 2d 41, 190 N.E.2d 825 (1963).

11 Escobedo v. Illinois, 375 U.S. 902 (1963). 
a general inquiry into an unsolved crime but has begun to focus on a particular suspect, the suspect has been taken into police custody, the police carry out a process of interrogations that lends itself to eliciting statements, the suspect has requested and been denied an opportunity to consult with his lawyer, and the police have not effectively warned him of his absolute constitutional right to remain silent, the accused has been denied "the Assistance of Counsel" in violation of the Sixth Amendment to the Constitution as "made obligatory upon the States by the Fourteenth Amendment," and that no statement elicited by the police during the interrogation may be used against him at a criminal trial. ${ }^{12}$

Despite the Court's refusal to go beyond the questions actually presented by the case, the principles announced in Escobedo will certainly be further refined and developed. Before considering the possibilities which lie ahead, it will be helpful to examine the constitutional principles which, assembled by the Court for the first time, led to the decision in Escobedo: the closely related "confession doctrine" (requiring exclusion of involuntary confessions) and privilege against self-incrimination, to be discussed in part II, and the right to counsel, considered in part III.

\section{II}

THE PRIVILEGE AGAINST SELF-INCRIMINATION AND THE "CONFESSION DOCTRINE"-DIFFERENT ORIGINS AND OBJECTIVES

The decision in Escobedo placed considerable emphasis upon the failure of the police to warn the accused of his "absolute constitutional right to remain silent."13 This right to remain silent originates in the privilege against self-incrimination, which is expressly guaranteed in the fifth amendment to the Federal Constitution. ${ }^{14}$ The effect of this provision on the development of American law over the last 200 years has been profound, far exceeding the apparent simplicity of its terms. The privilege has always been a source of protection to the citizen in Federal proceedings, and, recently, has been held to be obligatory upon the States through the fourteenth amendment. ${ }^{15}$ It may be invoked in a variety of cases: civil proceedings where answers might tend to estab-

12378 U.S. at 490-91. A more concise statement of the holding was later expressed: "We hold only that when the process shifts from investigatory to accusatory-when its focus is on the accused and its purpose is to elicit a confession-our adversary system begins to operate, and, under the circumstances here, the accused must be permitted to consult with his lawyer." Id. at 492.

13378 U.S. at 491.

${ }^{14}$ U.S. Const. amend. V: "[N]or shall he be compelled in any criminal case to be a witness against himself ...."

15 Malloy v. Hogan, 378 U.S. 1 (1964). 
lish criminal liability, ${ }^{16}$ administrative ${ }^{17}$ and legislative proceedings, ${ }^{18}$ and grand jury investigations. ${ }^{19}$

To require that the accused nuust be warned of his constitutional right to remain silent presupposes that he possesses such a right. Professor Wigmore las insisted that the privilege against self-incrimination is not one of the constitutional rights available to the accused at the police interrogation level but that this protection should apply only to proceedings where answers are legally compellable. He argued that police interrogations are subject only to the evidentiary rule requiring the exclusion of "involuntary" confessions..$^{20}$ While the lines which separate the two doctrines luave today become blurred, they nevertheless had distinctly different origins and objectives.

Justice Goldberg las stated that, although the privilege against selfincrimination is a fundamental part of our constitutional fabric, nonetheless "the law and the lawyers ... have never made up their minds just what it is supposed to do or just whom it is intended to protect."21 Although its origms may well antedate the common law, ${ }^{22}$ the privilege first appeared in the common law in the seventeenth century-a reaction to the notorious practices of the courts of the period, in particular to those of the Star Cliamber and the Higl Commission, where the accused was forced by torture and other forms of compulsion to confess his dehinquency. ${ }^{23}$

16 McCarthy v. Arndstein, 266 U.S. 34 (1924). There is a fundamental procedural difference between criminal and civil proceedings. In the former the defendant may refuse to take the stand, precluding the necessity of even raising the fifth amendment privilege against self-incrimination. In a civil proceeding he must take the stand but can refuse to answer any question, by a proper exercise of the privilege against selfincrimination.

17 ICC v. Brimson, 154 U.S. 447 (1894).

18 Quinn v. United States, 349 U.S. 155 (1955); Emspak v. United States, 349 U.S. 190 (1955).

19 Counselman v. Hitchcock, 142 U.S. 547 (1892).

208 WIGMORE, EVIDENCE § 2266 (McNaughton rev. 1961). See also McCormick, The Scope of Privilege in the Law of Evidence, 16 TEx. L. REv. 447, 452-57 (1938).

21 Murphy v. Waterfront Comm'n of N.Y. Harbor, 378 U.S. 52, 56 (1964), quoting from Kalven, Invoking the Fifth Amendment: Some Legal and Impractical Considerations, 9 BULL. AtOM. Scr. 181, 182 (1953).

22 It may have antedated the common law by over 1000 years, having its source in Talmudic Law in the plea ayn adom mesim atzmo rasha: "a person may not inculpate himself." Babylonian Talmud, Bava Kamina 74b. Rashi. Dean Griswold traces the privilege to the twelfth century controversy between the kings and the bishops wherein the kings sought to limit the bishops' examinations to purely ecclesiastical subjects. Griswold, THE FIFTe Axandment Today 2 (1955). Its common law usage is found in the maxim, nemo tenetue prodere se ipsum: "no one should be required to accuse himself."

235 Holdsworth, A History of ENGLish LAw, 184-96 (1924); Pittman, The Colonial and Constitutional History of the Privilege Against Self-Incrimination in America, 21 VA. L. REv. 763, 770 (1935). The privilege was entirely judge-made, the most notable case 
The rule requiring exclusion of "involuntary" confessions was not developed for another one hundred years. Although it too was a reaction to certain techniques employed to obtain needed information, the purpose of the "confession doctrine" was simply to avoid use of evidence deemed unreliable:

A free and voluntary confession is deserving of the highest credit ... but a confession forced from the mind by the flattery of hope, or by the torture of fear, comes in so questionable a shape when it is to be considered as the evidence of guilt, that no credit ought to be given to it; and therefore, it is rejected. ${ }^{24}$

The privilege against self-incrimination rests upon a determination that the use of abusive methods to compel an accused to give testimony which may be damaging to himself is an undesirable practice for a civilized society. The "confession doctrine" was not a reaction to the unfairness of coercing confessions from the accused, but simply a result of the belief that such confessions were unlikely to be reliable evidence. ${ }^{25}$

In America, the privilege against self-incrimination found its way into the early law of many of the colonies; ${ }^{26}$ it was presumably adopted in order to prevent the abuses that lad occurred in England. By 1800, at least seven States liad included the privilege in their own Bill of Rights. ${ }^{27}$ Today, the constitutions of all but two of the States contain a privilege against self-incrimination; the others, Iowa and New Jersey,

being that of John Lilbourne. See Scroop's Trial, 5 How. St. Tr. 1034, 1039 (1660); King Charles' Trial, 4 How. St. Tr. 993, 1101 (1649). Parliament finally did, however, react to these notorious practices by abolishing the Courts of the Star Chamber and the High Commission in 1641. 16 CaR. I. cc. 10, 11 (1641).

The privilege against self-incrimination at common law was apparently applicable in civil and equity cases as well as in criminal ones. BLACKSTONE, COMTMENTARTES 370, 446-47 (3d ed. 1771); Corwin, The Supreme Court's Construction of the Self-Incrimination Clause, 29 Micr. L. Rev. 1 (1930).

24 King v. Warickshall, 1 Leach 263 (1783).

25 Id. at 263-64.

26 In 1641, Massacinusetts respected the following restraints: "No man shall be forced by Torture to confesse any Crime against himselfe nor any other unlesse it be some Capital case where he is first fullie convicted by cleare and sufficient evidence to be guilty, After which if the cause be of That nature, that is apparent there be other conspiratours or confederates with him, Then he may be tortured, yet not with such Tortures as be Barbarous and inhumane." The Body of Liberties, \& 58 (1941), in The CoLony Laws of MassaChUSETTS 47 (1889). An early Connecticut restriction provided even more absolute protection for the accused. "It is ordered by the authority of this court that no man shall be forced by torture to confess any crime against himself." Pittman, The Colonial and Constitutional History of the Privilege against Self-Incrimination in America, 21 VA. L. Rev. 763, 779 (1935).

27 Penn. Declaration of Rights, amend. IX (1776); N.H. Bill of Rights, amend. XV (1784); Vt. Declaration of Rights, amend. X (1777); Va. Bill of Rights, 8 (1776); N.C. Declaration of Rights, amend. VII (1776); Mass. Declaration of Rights, amend. XII (1780) ; Md. Declaration of Rights, amend. XX (1776). 
recognize it as part of their existing law. ${ }^{28}$ The privilege against selfincrimination has been, of course, a part of the Federal Constitution since the fifth amendment was adopted in $1791 .^{29}$

The "confession doctrine" has also been a part of our American heritage for many years. By the end of the nineteenth century the Court had clearly enunciated the circumstances under which a confession would be excluded. The concern was still to see that the confession was trustworthy evidence, although the test had become somewhat more refined than the Enghish rule formulated a hundred years earlier: a confession could be admitted only if it was "made freely and voluntarily without compulsion or inducement of any sort."

The distinction between the "confession doctrine" and the privilege against self-incrimination was blurred by the Supreme Court in 1897 in Bram v. United States, ${ }^{31}$ a decision once characterized by Professor Wigmore as the "height of absurdity." ${ }^{22}$ The Court announced that the admissibility of a confession was controlled by the fifth amendment privilege against self-incrimination, but having said this proceeded to apply the voluntariness test of the confession doctrine:

A confession, in order to be admissible, unust be free and voluntary; that is, it must not be extracted by any sort of threats or violence, nor obtained by any direct or inplied promises, however slight, nor by the exertion of any improper influence. ${ }^{33}$

Since Bram, numerous cases involving the admissibility of confessions -in both State and Federal courts-have been decided by the Supreme Court, but until Escobedo, the Court in no case purported to rest its conclusion squarely on the privilege against self-incrimination. ${ }^{34}$ In its review of criminal convictions in the Federal judicial system the Court sometimes cited Bram, but continued to look to the voluntariness

28 In 32 States the wording of these provisions is either identical to, or only slightly different than, that of the fifth amendment. For specific wording of all the state provisions, See 8 WIGMORE, op. cit. supra note 20, at 319-23.

28 In the 100 years following the adoption of the fiftl amendment, there were only 15 reported Federal cases making specific reference to the privilege against self-incrimination, and even these were decided without reference to the fifth amendment. See cases collected in id. at 325. The explanation for this dearth of authority may lie in the fact that many American jurisdictions lad, during this period, adopted the English practice of the early 1800's whereby the accused was not permitted to testify, even in his own behalf. Corwin, supra note 23 , at 11 .

30 Wilson v. United States, 162 U.S. 613, 623 (1896).

31168 U.S. 532 (1897).

323 WiGMORE, EVIDENCE \& 821, at 240-41 n.2 (MCNaughton rev. 1961).

33168 U.S. at 542-43, quoting from 3 RUSSEII, CRTMEs 478 (6th ed.).

34 See note 12 supra and accompanying text. 
of the confession to determine if it had been freely made without coercion or inducement. ${ }^{35}$

In regard to state convictions the Court consistently refused, until the recent decision in Malloy v. Hogan, ${ }^{36}$ to treat the privilege against self-incrimination as constitutionally binding upon the states. ${ }^{37}$ The numerous decisions of the Supreme Court holding "involuntary" confessions inadmissible could not, therefore, have been grounded upon an absolute privilege against self-incrimination. Rather, the use of an involuntary confession was said to contravene the due process protections of the fourteenth amendment; in reality, the Court was simply applying the common law "confession doctrine." 38

The first major case in which a state conviction was reversed by applying the "confession doctrine" was Brown v. Mississippi, ${ }^{39}$ decided in 1936, in which the Supreme Court was faced with the problem of a confession elicited by means of extreme police brutality. In defense of its position, the State contended that the privilege against self-incrimination was not secured in the State courts by the Federal Constitution. The Court, however, did not even reach the merits of this argument for it concluded that the privilege against self-incrimination apphes when the accused is called as a witness and required to testify, but that "compulsion by torture to extort a confession is a different matter." Finding the use of a confession taken under such circumstances to be a demal of due process, the Court reversed the conviction.

The rationale for the decision in Brown v. Mississippi is unclear. The Court might have meant that the use by the police of abusive methods of interrogation which produce a confession would result in a violation of due process, thus providing the basis for the development of a test akin to the basic philosophy of the privilege against self-incrimination: Compelling the accused to incriminate himself is undesirable. Within a few years of Brown, however, the Court announced that "involuntary" confessions must be excluded because they are untrustworthy evidence. ${ }^{41}$ This was, of course, no more than a repetition of the original premise

85 See, e.g., Hardy v. United States, 186 U.S. 224, 229 (1902); Ziang Sung Wan v. United States, 266 U.S. 1, 15 (1924).

36378 U.S. 1 (1964). See notes $47-49$ infra and accompanying text.

37 E.g., Adamson v. California, 332 U.S. 46 (1947); Twining v. New Jersey, 211 U.S. 78, 88 (1908).

38 E.g., Leyra v. Denno, 347 U.S. 556 (1954); Watts v. Indiana, 338 U.S. 49 (1949).

39 Brown v. Mississippi, 297 U.S. 278 (1936).

$40 \mathrm{Id}$. at 285. See discussion of Professor Wigmore's position note 20 supra and accompanying text.

41 Lisenba v. California, 314 U.S. 228, 236 (1941). 
of the "confession doctrine." But this limited interpretation by the Court of the "confession doctrine" was only temporary. In the twenty-five years since Brown, the Court lias come to give the "confession doctrine" expanded application; techniques which fell far short of physical force were found to be capable of producing an "involuntary" confession. . $^{2}$ With this more refined notion of what constitutes a "voluntary" confession, the Court had to formulate an appropriate rationale for exclusion, for certainly many of the confessions lield to be inadmissible were perfectly reliable evidence. The Court ultimately conceded that reliability of evidence was only one of many factors:

It is now inescapably clear that the Fourteenth Amendment forbids the use of involuntary confessions not only because of the probable unrehability of confessions that are obtained in a manner deemed coercive, but also because of the "strongly felt attitude of our society that important human values are sacrificed where an agency of the government, in the course of securing a conviction, wrings a confession out of an accused against his will," . . . and because of the "deep-rooted feeling that the police must obey the law while enforcing the law; that in the end life and liberty can be as much endangered from illegal methods used to convict those thought to be criminals as from the actual criminals themselves." 43

Thus, the development of the exclusionary rule of the "confession doctrine" lias brought with it an implicit assimilation of the rationale for the privilege against self-incrimination. In fact, Justice Frankfurter once stated that the basis for the exclusionary rule was that the prisoner must not "be made the deluded instrument of his own conviction,"14 and found the origin of the rule in the reaction to the notorious practices of the Star Clramber. ${ }^{45}$ These very practices, we have already noted, were the impetus for the adoption by the common law courts during the seventeenth century of the privilege against self-incrimination. ${ }^{40}$ While

42 Haynes v. Washington, 373 U.S. 503 (1963) (accused not permitted to see his wife until after he had confessed); Townsend v. Sain, 372 U.S. 293 (1963) (a drug considered to have similar effects as truth serum had been given to the accused prior to his confession); Spano v. New York, 360 U.S. 315 (1959) (accused's sympathy was falsely aroused); Leyra v. Denno, 347 U.S. 556 (1954) (a psychiatrist, familiar with hypnosis, had been called to relieve the accused's sinus attack but had also questioned him). For a critical analysis of this development, see Paulsen, The Fourteenth Amendnent and the Third Degree, 6 Stan. L. REv. 411 (1954); Kamisar, What Is an "Involuntary" Confession? Some Comments on Inbau and Reid's Criminal Interrogation and Confessions, 17 RUTGers L. REv. 728 (1963).

43 Jackson v. Denno, 378 U.S. 368, 385-86 (1964). See also Blackburn v. Alabama, 361 U.S. 199, 207 (1960); Spano v. New York, 360 U.S. 315, 320-21 (1959).

44 Columbe v. Connecticut, 367 U.S. 568, 581 (1961), quoting from 2 Hawkns, PLEAS OF the Crown 595 (8th ed. 1824).

$45 \mathrm{Id}$. at 581 .

40 See note 23 supra and accompanying text. 
never again conclusively holding, at least until Escobedo, that it is the privilege against self-incrimination which protects the accused from abusive interrogation practices, the Court developed a doctrine, applicable to State and Federal courts alike, which closely resembled it.

When finally, in Malloy v. Hogan, ${ }^{47}$ the Court held that the privilege against self-incrimination is safeguarded against state action by the fourteenth amendment, it re-examined its earlier decisions regarding the admissibility of confessions, and cliaracterized them as having applied the privilege against self-incrimination to the state cases in substance although not in name. The Court began by stating that Bram v. United States $^{48}$ established the rule that the use of involuntary confessions violated the fifth amendment privilege against self-incrimination. This same test, the Court noted, came to be applied in state cases as well:

The marked shift to the federal standard in state cases . . . reflects recognition that the American sytem of criminal prosecution is accusatorial, not inquisitorial, and that the Fifth Amendenent privilege is its essential mainstay. ... Governments, state and federal, are thus constitutionally compelled to establish guilt by evidence independently and freely secured, and may not by coercion prove a charge against an accused out of his own mouth. Since the Fourteenth Amendment prohibits the States from inducing a person to confess through "sympathy falsely aroused," .. . or other like inducement far short of "compulsion by torture," ... it follows a fortiori that it also forbids the States to resort to inprisonment, as here, to compel him to answer questions that might incriminate him. ${ }^{49}$

In the Court's view, then, what appeared to be a refined version of the "confession doctrine," was in reality the privilege against selfincrimination all along. The decision in Escobedo leaves little doubt that the merger of the "confession doctrine" with the privilege against selfincrimination is now complete.

Moreover, it is apparent that the Court intended the privilege to be given meaningful effect. The opinion in Escobedo seems to imply that the interrogating officers have a duty to warn the accused of his right to remain silent. ${ }^{50}$ The Court las never before expressly held that ar-

47378 U.S. 1 (1964).

48 See notes $36-38$ supra and accompanying text.

49378 U.S. at 7-8.

50 See 378 U.S. at 491 . The Court did not expressly state that the accused must be informed of his right to remain silent and his right to counsel, holding only that a confession taken where counsel had been requested and denied is inadmissible, under the precise circumstances of the case. But the Court expressly observed that Escobedo had not been advised of his "absolute right to remain silent;" it is obvious that the "guiding hand of counsel," 378 U.S. at 486, (quoting from Powell v. Alabama); is seen by the Court to be most needed to insure that the defendant does not unwittingly waive his 
resting officers have such a duty, and prior to Escobedo the courts of appeal had not treated the problem consistently. ${ }^{51}$ Two early decisions of the Supreme Court came close to holding that a warning is not required, stating:

And it is laid down that it is not essential to the admissibility of a confession that it should appear that the person was warned that what he said would be used against him, but on the contrary, if the confession was voluntary, it is sufficient though it appear he was not warned. ${ }^{22}$

Although these cases have never expressly been disapproved, it seems clear that they cannot stand in the face of the Court's expanded doctrine of waiver. ${ }^{53}$ The accused can only make a knowledgeable waiver of his constitutional right to remain silent if he is cognizant of the existence of this right. If it was not clear at the time these cases were decided, it is now settled that the privilege against self-incrimination extends in some measure to the period of interrogation. Perhaps a distinction could be drawn between a defendant aware of his right to remain silent and one ignorant of this right. ${ }^{4}$ The Court in Escobedo did not choose this approach, holding simply that the accused was denied the right to counsel where he had not been informed of his right to remain silent. ${ }^{55}$

right to remain silent. At the least, then, Escobedo v. Illinois requires exclusion of confessions ohtained from an interrogation during which the accused is not permitted to consult with counsel nor advised of his right to remain silent. See notes $62-65$ infra and accompanying text (on qualified right to counsel). But whether the police, as a matter of constitutional law, must recite the catalogue of rights of the accused where counsel is provided has yet to be determined.

51 A case requiring a warning is Wood v. United States, 128 F.2d 265 (D.C. Cir. 1942). Among those not requiring a warning are, e.g., United States v. Parker, 244 F.2d 943 (7th Cir. 1957); United States v. Scully, 225 F.2d 113 (2d Cir. 1955). The Code of Mibtary Justice requires that a warning be given all military personnel of their right to remain silent and that anything they say may be used against them. Uniforn Code of Military Justice, 10 U.S.C. $\$ 831$ (b) (1958). Apparently Texas is the only state that has a statutory requirement making a warning mandatory. TEX. Code CRTM. Proc. art. 727 (Vernon, 1948). The Stanford Law Review sent out letters in 1952 to 90 police stations questioming if they warned the accused of his rights. The majority of those replying answered in the affirnative, not because they felt that they were required by law to do this, but rather to insure that the confession would be voluntary. See Comment, 5 SrAN. L. REv. 459 (1953).

62 Wilson v. United States, 162 U.S. 613, 623 (1896); Powers v. United States, 223 U.S. 303,313 (1912). The statements made by the defendants were not actually confessions, but incriminating admissions. Apparently, the Court felt constrained to justify these holdings because it commented in both cases that it was not convinced that the defendant would have refused to speak even if he had known of his right to remain silent.

53 See notes 114-17 infra and accompanying text.

54 See notes 67-68 infra and accompanying text.

65 See note 50 supra. 


\section{III \\ THE RIGHT TO COUNSEL}

The decision in Escobedo leaves unanswered important questions regarding the scope of the right to counsel at the interrogation stage. The Court purported to rest its conclusion on the right to counsel, but as we have seen, this right was closely intertwined with the privilege against self-incrimination. It is this relationship which makes the decision difficult to analyze: Is the right to counsel during interrogation himited to those cases where the police have failed to warn the accused of his constitutional right to remain silent or is it an absolute protection always available to the accused regardless of whether he has been so warned? To better understand the nature of this right enunciated by the Court, a brief study of the historical development of the sixth amendment right to counsel will prove useful.

The right to counsel, in sixteenth century England, was a limited one. ${ }^{56}$ The right was assured only in misdemeanor cases; in felony and treason trials the advice of counsel was limited to questions of law only. In these cases, the defendant was forced to plead to the indictment and present his defense on the factual issues without legal assistance. ${ }^{57}$ Gradually, these restrictions were relaxed until, by 1836 , the assistance of counsel for all types of criminal offenses was a matter of right. ${ }^{58}$ At the very least, then, the sixth amendment's guarantee of counsel was intended to guarantee the right to representation by counsel, regardless of the nature of the offense.

To suggest, however, that the intention of the framers of the sixth amendment was to guarantee that counsel be permitted for police interrogations as they exist today would be capricious, since such investigations were unknown in 1791 when that amendment was adopted. The modern police force, with highly sophisticated techniques of investigation, bears little resemblance to that of England in earlier days. The organization most comparable to the police force of today was primarily an enforcenrent body, concerned with protecting against crime. ${ }^{59} \mathrm{Re}-$

56 Comment, An Historical Argument for the Right to Counsel during Police Interrogation, 73 Yale L.J. 1000, 1018-34 (1964); 1 Stephen, A History of tHe Crimtnas LAW OF ENGLAND 244-72 (1883).

57 A concurrent development was the use of witnesses for the presentation of the factual issues. Frequently, what constituted a question of law was narrowly construed, thus limiting even further the right to counsel. See Russel's Case, 9 How. St. Tr. 577 (1683); Raleigh's Case, 1 How. St. Tr. 236 (1603).

586 \& 7 WIIL. 4, c. 114, $\$ 1$ (1836). The fact-law distinction in the treason cases had been abrogated at an earlier date. $7 \& 8$ WIIL. 3, c. 3 (1695).

50 Maituand, Justice and Police 105-08 (1885). 
sponsibility for investigation of the facts and examination of the accused devolved upon the judicial bodies-the Privy Council, the Star Chamber, and the magistrates' hearings. ${ }^{60}$ It was not until 1879 that Parliament established the police force as an official body with investigatory powers totally independent of the magistracy. ${ }^{61}$ The development of the American police force closely paralleled that of the English, expanding the scope of its operations by the latter part of the nineteenth century.

It miglit be argued that the right to counsel does not extend beyond those times during which counsel has historically assisted defendants in criminal prosecutions: the pleading and trial stages. In Massiah, the Court rejected this view, holding that the accused may not be denied the assistance of counsel during a post-indictment questioning, and emphasizing that this was the only time when legal assistance would have been of substantial benefit to the accused. From this, two interpretations of the scope of the right to counsel during interrogation may be advanced.

The first of these would make the right to counsel during interrogation a qualified right limited to those cases in which the absence of counsel would operate to the detriment of the defendant. The argument is that only in such cases where important rights are irretrievably lost at an early point in the criminal proceeding will the accused have been denied the effective assistance of counsel for the traditional stages of the criminal prosecution at which counsel has been permitted: pleading and trial. ${ }^{62}$ The majority opinion in Escobedo, interestingly enough, voiced the opinion that the denial of counsel during interrogation in the case before them "would make the trial no more than an appeal from the interrogation. .. ." ${ }^{83}$ In addition, it distinguished an earlier case, Crooker v. California, ${ }^{64}$ on the ground that, although the defendant there had been denied counsel, he had been "explicitly advised by the pohice of his constitutional right to remain silent and not to 'say anything' in re-

60 Id. at 129-35; 1 STEPHEN, op. cit. supra note 56 , at 182-83.

6142 \& 43 VICT., c. 22 (1879). This was the culmination of a series of Parliamentary decrees which first authorized a police force only for London, 10 GEo. 4, c. 44 (1829); then for the major cities of England, 2 \& 3 VICT., c. 93 (1839); and finally for the rural areas as well, $19 \& 20$ Vicr., c. 69 (1856).

62 This approach is similar to the analysis first put forth in Powell v. Alabama, 287 U.S. 45 (1932), in which the Court first held that counsel must be provided the indigent defendant in all capital cases, in order to insure that his right to be beard would not be prejudiced and to prevent a violation of the due process requirements of the fourteenth amendment. The argument for a conditional right to counsel during interrogation is comparable in that it would limit the right to counsel only to those instances where the denial of counsel would prejudice the defendant's right to the assistance of counsel at the pleading and trial stages, as guaranteed to him by the sixth amendment.

63378 U.S. at 487.

64357 U.S. 433 (1958). 
sponse to questions . . ." ${ }^{85}$ It might be argued, therefore, that had the interrogating officers effectively warned Escobedo of his constitutional right to remain silent, there would have been no need to provide counsel. This assumes, of course, that the only useful contribution of counsel to the accused at this stage is to warn him of his constitutional right to remain silent.

The alternative is to view the right to counsel broadly, interpreting it to be an absolute guarantee for the accused for all stages of a "criminal prosecution," and not limited only to the pleading and trial stages. This approach has considerable merit. It recognizes that, with the development of the police into a highly sophisticated investigatory organization, the forces of the state are brouglit to bear against the accused much sooner than they were in an earlier day. Therefore, to insure as complete protection of the accused as was given at the time the sixth amendment was adopted, the assistance of counsel is required during the initial stages of a "criminal prosecution" as well as during the pleading and trial. $^{.6}$

It will doubtless be argued that an absolute riglit to counsel during interrogation is an arbitrary rule in that it presumes prejudice to the accused in all cases in which counsel is not provided. It must be recognized, however, that limiting the right to counsel to those cases in which the pohice have not warned the accused of his right to remain silent is no less arbitrary, for it assumes that, liaving been so warned, no prejudice to the accused can result. Indeed, it is possible to postulate two other interpretations of the scope of the right to counsel in Escobedo which, although not as convincing as either the "absolute" or "conditional" arguments, are worthy of brief consideration.

The first of these we may call a "limited" riglit to counsel. Two dissenting justices in People v. Dorado, ${ }^{67}$ a case recently decided by the California Supreme Court following the rule of Escobedo, suggested that

65378 U.S. at $491-92$. The Court singles out this one factor but, in truth, this had been only one of many factors used to support the conclusion that there had not been a violation of due process. The Court mentioned another case where the accused had been denied counsel, Cicenia v. LaGay, 357 U.S. 504 (1958), stating that it added nothing to Crooker. Interestingly enough, there had been no inention in the opinion of this case that the defendant had been informed or actually knew of his right to remain silent.

${ }^{66}$ If this be true, Justice Stewart's position favoring the extension of the sixth amendment to the post-indictment period but not to the interrogation stage, because the latter is not a judicial proceeding, is tenuous. Compare Massiah v. United States, 377 U.S. 201 (1964), with his dissent in Escobedo v. Illinois, 378 U.S. at 493-95 (Stewart, J., dissenting). Both of these periods are critical stages which require the aid and assistance of qualified counsel. This concern with formality disregards their essential similarity-the disadvantageous effect upon the accused if he be interrogated without the assistance of counsel.

6762 A.C. 350, 376-80, 42 Cal. Rptr. 169, 186-88 (1965) (Burke, J., dissenting). 
where the circumstances of the case indicate that the accused was in fact aware of his constitutional rights, counsel need not be furnished, although the police failed to give any warning. This view would seem to be foreclosed by the Escobedo decision itself, for it is clear that the defendant in that case did in fact know that he was not required to answer questions. $^{68}$

The other view is that the accused would be able to show a denial of counsel, whether or not he had been warned of his right to remain silent, only upon a showing that he had been prejudiced by the absence of legal assistance. The defendant might, for example, prove that had counsel been provided, he would not have confessed. This approach has, at first examination, considerable appeal because it would hmit the right to counsel to those cases where counsel was most needed. It would, however, require courts to indulge in nice calculations, as they were forced to do following the decision in Betts v. Brady, ${ }^{69}$ as to the amount of prejudice caused to the accused by the denial of counsel. It would seem that the rejection of Betts in Gideon v. Wainreright, ${ }^{70}$ and the decision in Escobedo, were reactions by the Supreme Court to such burdens. They appear to indicate a desire on the part of the Court to formulate procedural rules which would eliminate that duty.

Since the "limited" right to counsel seems foreclosed by the opinion in Escobedo, and since the approach suggested above, based on a showing of prejudice in each case, is unhikely to be acceptable to the Court, the choices seem to narrow down to two: the "conditional" and the "absolute" riglnt to counsel. Inevitably the Court will find it necessary to choose between these alternatives. ${ }^{71}$ The choice could conceivably be postponed for some tinie, as many cases can be resolved on more limited grounds: that the warning was a sham and not effective, that the accused's alleged waiver of his right to remain silent, for whatever reason, was not an intelligent one, or that the confession was not legally voluntary. However, the case of the reasonably intelligent accused, intentionally waiving his constitutional right to remain silent and voluntarily confessing without the assistance of counsel, must ultimately arise, compelling the Court to choose between a "conditional" and an "absolute" right to counsel at interrogation.

68 See 378 U.S. at 485 n.5.

69316 U.S. 455 (1942). See note 4 supra.

70372 U.S. 335 (1963).

71 A recent decision by the Oregon Supreme Court reflects this dilemma. Citing Escobedo, it held that a confession obtained without warning the accused of his constitutional right to remain silent is inadmissible, but then concluded that, "Whether law enforcement officers must in addition advise an accused of his right to counsel . . we need not now decide." State v. Neely, — Ore. —, 395 P.2d 557, 561 (1964). 
It is to be hoped that the Supreme Court will ultimately declare the right to counsel to be absolute. Even if the police, in all good faith, warn the accused of his right to remain silent, this cannot be expected to have the effect of an admonition from counsel. It is questionable whether the uncounseled layman can really appreciate the full significance of the privilege against self-incrimination in the adversary system. Notwithstanding his awareness of his right to remain silent, it may momentarily appear desirable to answer some or all of the questions put to him. He may believe that by answering questions lie can persuade his questioners of his innocence. A voluntary disclosure often may be advantageous but sometimes, as in the case of Escobedo, a simple admission of complicitly can, unbeknownst to the defendant, be as legally damaging as a complete confession of guilt.

Further, the integration of counsel into the interrogation proceeding will be the most complete safeguard against the use of abusive techniques of interrogation. As we liave already noted, the refinement by the Court of the "confession doctrine" was an attempt to curb the less coercive but equally undesirable police practices. ${ }^{72}$ However, this effort lias not been altogether effective. A recent study reported that "Enougl evidence is at hand to warrant the conclusion that the police subject persons in custody and under interrogation to many kinds of force and intimidation."73 The burden of proof upon the accused has often been insurmountable; his unsubstantiated testimony is in most instances directly contradicted by the police. ${ }^{74}$

Admittedly, if the confession is found to be "involuntary," it is inadmissible into evidence against the accused. But there are many techniques commonly used by the police that do not result in an "involuntary" confession but which still miglit be termed morally objectionable by a civilized society. Textbooks addressed to police officers often recommend interrogation techniques designed to elicit confessions from reticent suspects which can be best described as devious. False sympathy, emotional pressure, and psychological trickery are considered legitimate devices for the skillful interrogator. ${ }^{75}$ One such author conceded that

${ }^{72}$ See note 42 supra and accompanying text.

73 Simtr, Poutce Systems In the United States 324 (2d rev. ed. 1960). Two major public studies have touched upon the subject. See U.S. NATIONAI CoMmassion on LAw Observance and ENforcenaent, Report on LawlessNess in ENFORCEMENT OF the LaW (1931); Equal Justice under the Law, in 5 U.S. Commassion ON CIvII RIGHTS REPORTS, JUSTICE 5-28 (1961).

74 Columbe v. Connecticut, 367 U.S. at 574 (1961).

75 See Inbad \& Rem, Crtumnat Interrogation and Confessions (1962); KmD, Police Interrogation (1954); Gerber \& Schroeder, Crominat Investigation and INTERROGATTON (1962). The Inbau and Reid book is a very specific and highly illuminating study of recommended techniques of interrogation. A paraphrase of the author's advice 
these methods are "less refined" than those considered appropriate for the transaction of everyday affairs by and between law abiding citizens. ${ }^{70}$ It is open to question whether the "confession doctrine" has been an altogether satisfactory means of ehminating these subtle methods designed to persuade the accused to waive his constitutional right to remain silent. ${ }^{77}$

Another judicial effort to curb some of the abuses arising from the prolonged incommumicado interrogation was the development by the Supreme Court of the so-called $M c N a b b-M a l l o r y$ rule. This rule provides for the exclusion of evidence obtained by the police after failure to bring the accused before a United States Commissioner within a reasonable time. However, the federal courts have not interpreted this so stringently as to deny police enough time to discharge their administrative duties ${ }^{78}$ and to question the accused in private. ${ }^{79}$ In addition, since the $M c N a b b-M a l l o r y$ rule is but a rule of court derived from a pro-

to the would-be interrogator might read: Impress the accused with your certainty of his guilt, and comment upon his psychological symptoms of guilt, such as the pulsation of a carotid artery, nail biting, dryness of the mouth, etc.; smoking should he discouraged because this is a tension-reliever for the guilty subject trying desperately not to confess; the sympathetic approach-anyone else under such circumstances would have acted the same way, suggest a less repulsive reason for the crime, and, once he confesses, extract the real reason, condemn the victim, the accomplice or anyone else upon whom some degree of moral responsibility might be placed; understanding approach-a gentle pat on the shoulder, a confession is the only decent thing to do, I would tell my own brother to confess; forceful approach-exaggerate the charges against the accused, sweet and sour technique (one policeman is hostile to him while other acts as his friend); interrogation of the recalcitrant witness-at first be gentle and promise him pohice protection, then, if he still refuses to talk, attempt to break the bond of loyalty hetween him and the accused or even accuse him of the offense and interrogate him as if he were the offender.

The book written by Lt. Kidd provides fascinating reading for the novice. The following paraphrased extracts offer examples: The officer should not interrogate in a business office where there might he a recording device because he may make some statements which would be embarrassing if played back in court to rebut his testimony; feed upon suspect's likes and dislikes-love of mother, hatred of father, concern for children; never release pressure even when tears begin to flow; don't allow the accused any form of tension release at a critical moment in the questioning, such as a cigarette, a drink of water, or a trip to the washroom; play two co-conspirators against each other (often termed bluffing on a split pair)-claim that one talked and blamed the other, possibly using a false recording to substantiate this claim, continually take one out separately but never question him-the other will believe it necessary to tell his side of the story; aggressive approach-blame accused for crimes he didn't commit, play on the fact that many defendants fear the mental asylum more than jail.

An interesting article in the Gerber and Schroeder hook noted the similarity between the methods of interrogation used today and the practices of the German Inquisition.

See Gerber \& Schroeder, op. cit. supra at 361-62.

76 INBAU \& RED, op. cit. supra note 75, at 206.

77 See notes 99-100 infra and accompanying text.

78 Heideman v. United States, 259 F.2d 943 (D.C. Cir. 1958).

70 Goldsmith v. United States, 277 F.2d 335 (D.C. Cir. 1960). 
cedural statute, ${ }^{80}$ and not a constitutional principle, ${ }^{81}$ it is not obligatory upon the States. Although many of the states have statutes similar to that of the federal system, ${ }^{82}$ only the Supreme Court of Michigan has ever applied the $M c N a b b$-Mallory rule, ${ }^{83}$ and this decision was overruled, or at least modified, only two years later. ${ }^{84}$

The other arguments in support of an "absolute" right to counsel during interrogation may be briefly stated..$^{85}$ Counsel would be an additional witness to the interrogation proceeding. He could advise the accused of his constitutional rights and their proper application-when to remain silent, when to bargain for a lesser charge, and on other tactical matters. He would be better able to prepare an adequate defense for his client, determining the facts earher, capitalizing on fresh leads, and assessing the strength of the district attorney's case against the accused. The effect upon the entire legal system would be significant. For example, it lias been estimated that the heaviest number of criminal convictions result from pleas of guilty or nolo contendere, ${ }^{86}$ thereby precluding the necessity of holding a complete trial. If the presence of counsel during the police interrogation will guarantee that the trial is something more than "an appeal from the interrogation," most likely be a marked increase in the number of criminal cases brought to trial.

The arguments in support of excluding counsel from the interrogation proceeding are less persuasive. It is argued that if the accused be

80 Compare United States v. Carignan, 342 U.S. 36, 46 (1951) (Douglas, J., concurring), stating that the purpose of McNabb, v. United States, 318 U.S. 332 (1943), was to rid the Federal systen of closed door interrogations, which are the "breeding grounds for coerced confessions," with Inbau, The Confession Dilemma in the United States Supreme Court, 43 III. L. REv. 442, 455-57 (1948) claiming that the original purpose of the Congressional statute on which $M c N a b b$ v. United States was grounded was to prevent Federal marshals from defrauding the governnient on mileage fees in the delivery of prisoners.

81 For an argunent that the $M c N a b b-M a l l o r y$ Rule is a constitutional right, see Broeder, Wong Sun v. United States: A Study in Faith and Hope, 42 NEB. L. REv. 483, 557-65 (1963).

82 The Court has noted forty-four such statutes in $M c N a b b .318$ U.S. at 342.

83 People v. Hamilton, 359 Mich. 410, 102 N.W.2d 738 (1960).

84 People v. Harper, 365 Mich. 494, 113 N.W.2d 808 (1962). Many states permit by statute a proscribed period of time before the police are required to bring the accused before a nuagistrate. See CAI. PEN. CODE \& 825 ("without unnecessary delay, and, in any event, within two days after arrest, excluding Sundays and holidays").

85 See Conment, 73 YaLE L.J. 1000, 1048-51 (1964); Weisberg, Police Interrogation of Arrested Persons: A Skeptical Viezw, 52 J. CRTM. L., C. \& P.S. 21 (1961); Newman, Pleading Guilty for Considerations: A Study of Bargain Justice, 46 J. CRmM. L., C. \& P. S. 780 (1956).

88 Goldstem, The State and the Accused: Balance of Advantage in Criminal Procedure, 69 YALE L.J. 1149, 1163, n.37 (1960).

87 See note 63 supra and accompanying text. 
permitted the assistance of counsel during interrogation, many wrongdoers will go unpunished. In fact, Justice Jackson argued that, "a lawyer worth his salt will tell the suspect in no uncertain terms to make no statement to pohice under any circumstances." 88 Does this mean that law enforcement will be inefficient when accommodated to the constitutional guarantees of the individual, and can be efficient only when the individual is unaware of his rights? ${ }^{80}$

It might be argued that the alarming crime figures ${ }^{90}$ in the United States justify capitalizing on the ignorance of the accused in order to maintain an orderly society, although a direct correlation between the certainty of apprehension and punishment and the rate of criminal offenses is by no means definite in all cases. ${ }^{91}$ In some cases, of course, the admonition of counsel will go unheeded, and the accused will confess nonetheless. In others, upon being informed of his constitutional right to remain silent, the accused will refuse to cooperate with the police. The police will then have to rely solely on their own investigatory resources for a conviction. If the costs of investigation are prohibitive or if sufficient evidence cannot be obtained by a reasonably diligent effort, charges will not be filed against the accused or, if filed, will be dropped. It is difficult at the present time to predict how many cases will fall into this category. ${ }^{92} \mathrm{~A}$ very limited but interesting study performed several years ago in two of the smaller cities in California tended to substantiate the claim made by most police officials that statements elicited from the accused during interrogation do play a major role in criminal enforcement. ${ }^{93}$

88 Watts v. Indiana, 338 U.S. 49, 59 (1949) (concurring opinion). The truth of this statement is assumed by the Court in Crooker v. California, 357 U.S. 433 (1958). 89 See Escobedo v. Illinois, 378 U.S. 478, 490 (1964).

90 There were $21 / 4$ million serious crimes committed in the United States in 1963, a $9 \%$ increase over the previous year's crinie rate, and a $30 \%$ increase over that of 1958 . Some other alarming figures for 1963 were: over $\$ 785$ million worth of property was stolen; $91 \%$ of the murders, $84 \%$ of the negligent manslauglters, and $76 \%$ of the aggravated assaults were cleared up by the police, but $61 \%$ of the robberies, $73 \%$ of the burglaries, and $80 \%$ of the larcenies remained unsolved. U.S. DEPT. OF JUSTICE, CrJMeE in the United States, Uniforar Crime Reports, 1-22 (1963).

91 Gardiner, The Purposes of Criminal Punishment, 21 MODERN L. REv. 117, 125 (1958). "[G]reater certainty of detection and of punisliment does deter many potential offenders, but where strong passions or deep psychological motivates are involved, the prospect of detection and punisliment have relatively little effect."

92 The author was told by several law enforcement officers that confessions were an extrenely important, if not an absolutely necessary police tool, in robbery and burglary cases. These crimes already are among those with the lowest solution rates; see statistics for 1963 , note 90 supra.

93 The survey showed that confessions or admissions were elicited from over $50 \%$ of those arrested and from over $75 \%$ of those charged. Barrett, Police Practices and the Law-From Arrest to Release or Charge, 50 CaIIF. L. Rev. 11, 35-44 (1962). 
If the Court should require that counsel be provided for all those who do not have representation of their own, additional administrative and financial burdens will be placed upon the system. Since counsel must now be provided in all other stages of the "criminal prosecution," most likely the Court will not permit an exception to this rule for the interrogation period. Counsel must now be provided by the State for the preliminary hearing stage; ${ }^{94}$ the additional burden placed on the legal system by requiring the appointment of counsel for interrogations held within the police station should not, therefore, be substantial. Extending the right to counsel to "interrogations" conducted outside the police station will, of course, raise more serious problems.

Even if the Court should one day hold that Escobedo established only a conditional right to counsel - conditioned, that is, on the failure of the police to warn the accused of his constitutional right to remain silent-that case would nonetheless represent a significant stride forward in the protection of the individual suspected or accused of crime. The decision requires, at the least, that the police either provide counsel or adequately warn the accused of his constitutional right to refrain from answering questions or making statements. That warning will, no doubt, have considerable effect in numerous cases; it neutralizes a powerful weapon formerly in the hands of all police interrogators: a persistently asked question, which carries with it the implication that an answer is expected. ${ }^{95}$

This is so, certainly, when the prisoner has never been told that he need not answer and when, because his commitment to custody seems to be at the will of his questioners, he has every reason to believe that he will be held and interrogated until he speaks. ${ }^{96}$

The manner in which the police present the warning to the accused will be extremely significant. A formal explanation by the officer, given with appropriate emphasis, will be impressive, whereas a cursory recital may have little effect. ${ }^{97}$ The Court may, if there has not been a good faith attempt to warn the accused, find that the warning was not effec-

94 White v. Maryland, 373 U.S. 59 (1963).

95 Columbe v. Connecticut, 367 U.S. 568, 575 (1961).

86 Id. at 575-76.

97 As an aftermath of the decisions in Escobedo and Dorado, one of the northern California police departments has recently instructed its officers to make the following warning to the accused: "You do not have to say anything unless you wish to." Obviously, a statement such as this pays ritualistic observance to the requirements established by the courts but will not always serve to impress upon the accused the significance of his constitutional rights. A more appropriate admonition would be: "We want to warn you that because of your constitutional right to remain silent, you may refuse to answer any questions without prejudice to your position." 
tive..$^{88}$ It is, of course, somewhat of an anomaly to rely upon the police to warn the accused of his right to remain silent when their job will become more difficult if he elects to exercise this privilege.

In many cases, the State will be hard pressed to obtain a conviction if unable to elicit conclusive, or at least corroborative, admissions from the accused. Despite this apparent advantage, the accused may be reluctant to remain silent, fearing that he might antagonize his questioners and thereby prejudice the ultimate disposition of his case. Because the privilege against self-incrimination is for his benefit, the accused can intentionally waive his right to remain silent. ${ }^{90}$ Not realizing the full significance of such a waiver and subject to the police pressures described earher, he may too readily take this step. Any waiver should be closely scrutinized by the Court to determine if it was both intelligent and intentional. ${ }^{100}$

Moreover, the requirement that the accused must be warned of his right to remain silent will provide an additional ground upon which to assess the admissibility of the confession. There will be, in each case, a separate finding looking solely to the adequacy of the warning given by the police and the waiver by the accused. Of course, the burden of proof on appeal will be with the accused to show that the trial court erred in finding that he had waived his constitutional rights. ${ }^{101}$

Now that it is clear that the privilege against self-incrimination, apphicable in State court proceedings as well as Federal, applies to interrogation, it seems likely that it will be constitutionally impermissible to impute an admission to the defendant from his silence. In some jurisdictions, testimony has been allowed to the effect that the accused stood inute when statements concerning his guilt were made in his presence, statements which would ordinarily have called forth a denial from an innocent: person. ${ }^{102}$ If the accused has a constitutional right to remain silent, then

98 Cf. Haley v. Ohio, 332 U.S. 596 (1948), where the Court rejected a confession signed by the accused that stated he had been informed of his constitutional rights. "Moreover, we cannot give any weight to recitals which merely formalize constitutional requirements." Id. at 601 .

90 Rogers v. United States, 340 U.S. 367, 371 (1951); Brown v. Walker, 161 U.S. 591, 597 (1896).

100 It might be suggested that no waiver of the privilege against self-incrimination should be permitted until the accused has had an opportunity to first consult with a lawyer. Cf. Adams v. United States ex rel. McCann, 317 U.S. 269, 282 (1942) (Douglas, J., dissenting), suggesting that the waiver of the right to jury trial in the absence of legal advice cannot be intelligent or competent. Such a view could conceivably be applied to the right to counsel situation.

101 Johnson v. Zerbst, 304 U.S. 458, 468 (1938).

102 Sparf \& Hansen v. United States, 156 U.S. 51 (1895) ; Rocchia v. United States, 78 F.2d 966 (9th Cir. 1935); Dickerson v. United States, 65 F.2d 824 (D.C. Cir. 1933). Contra, 
his silence presumably cannot be used as the basis for an imputation of an admission of guilt. ${ }^{103}$

\section{IV}

POTENTIAL LIMITATIONS ON THE RIGHT TO COUNSEL DURING INTERROGATION

Massiah and Escobedo taken together pose serious problems for those charged with the duty of law enforcement. Massiah fastened upon the indictment as an event of constitutional significance, and found a denial of counsel in the informal "interrogation" conducted by the defendant's former accomplice acting as an "agent" for the prosecution. In Escobedo, the Court found the absence of a formal indictment not controlling, and pointed to a combination of factors whicli demonstrated that the state had instituted a "criminal prosecution" against the accused:

Where ... the investigation is no longer a general inquiry into an unsolved crime but has begun to focus on a particular suspect, the suspect has been taken iuto police custody, the police carry out a process of interrogations that lends itself to eliciting incriminating statements, the suspect lias requested and been demied an opportunity to consult with his lawyer, and the police have not effectively warned him of his absolute constitutional right to remain silent, the accused has been denied "the Assistance of Counsel" . . . .104

The implications of these decisions depend in large part upon the extent to which the Court views the above factors in Escobedo as delimiting conditions.

\section{A. Where Investigation Has "Focused" on a Particular Defendant}

Obviously aware of the implications for law enforcement, the Court in Escobedo attempted to limit the applicability of the rule to those circumstances where the investigation ceased to be a "general inquiry into an unsolved crime," but rather had "focused" on the accused. The Court's attempt to draw this hine is not without significance: it indicates judicial concern lest legitimate investigatory practices of the police be unduly hampered. It takes care of the obvious cases, such as the spontaneous, unsolicited confession. ${ }^{105}$ However, because this line defies a

United States v. Lo Biondo, 135 F.2d 130 (2d Cir. 1943); Yep v. United States, 83 F.2d 41 (10th Cir. 1936); McCarthy v. United States, 25 F.2d 298 (6th Cir. 1928).

$103 \mathrm{~A}$ similar problem is the judicial procedure permitted by some states whereby the court and counsel may comment upon the accused's failure to take the stand in his own defense. See Adamson v. California, 332 U.S. 46 (1947). Presumably, as a result of Malloy, this practice nuay no longer be valid.

104378 U.S. at $490-91$.

105 See People v. Dorado, 62 A.C. 350, 366, 42 Cal. Rptr. 169, 179 (1965): "Nothing 
more precise identification, this will be a fertile source of litigation, at least in the near future, as the Court attempts to develop rules for the guidance of the lower courts. ${ }^{106}$

\section{B. Interrogation}

Escobedo, it will be recalled, defines "interrogation" as a process of questioning "that lends itself to eliciting incriminating statements." This, too, would appear to exclude the spontaneous confession. ${ }^{108}$ Theoretically, use of an undercover agent, a teclinique used to advantage by the police, may involve engaging in "interrogation" of this kind, where the agent is attempting to elicit incriminating statements from criminal offenders. That he is in disguise and that the questioning might be informal would not appear to alter this result, for as the Court pointed out in Massiah:

[I]f such a rule [requiring counsel] is to have any efficacy it must apply to indirect surreptitious interrogations as well as those conducted in the jailhouse. In this case, Massiah was more seriously imposed upon ... because he did not know that he was under interrogation by a government agent. ${ }^{109}$

Moreover, too broad a reading of "interrogation," where suspicion has "focused," could call into question the constitutionality of numerous

that we have said, of course, should be interpreted to restrict law enforcement officers during the investigatory stage from securing information from one who is later accused of the crime or from obtaining answers to their questions. Indeed, any statements obtained without coercion, including, of course, the unsolicited, spontaneous confession, given in the absence of the requirements for the accusatory stage, may be admitted into evidence."

108 Where the line will finally be drawn remains to be seen. The difficulties are considerable. Consider the following hypothetical. A house is robbed in a suburban neighborhood. Unable to find fingerprints or other useful evidence, the police begin a door-to-door inquiry, asking those residing in the immediate vicinity whether they heard or saw anything suspicious on the might of the robbery, or whether they have any other information which might be of significance. Presumably, the investigation is, at this point, so general that no right to counsel problem has yet arisen. Suppose, however, that the officers are told by several neighbors that $M r$. Jones was acting suspiciously, and on the night in question was seen carrying several boxes into his house. When, armed with this information, the police call on Jones to question him, nust they inform him of his rigbt to counsel?

107378 U.S. at 491.

108 See also note 105 supra and accompanying text.

109377 U.S. at 206, quoting from Massiah v. United States, 307 F.2d 62, 72-73 (1962) (Hays, J., dissenting). This is not to suggest that the use of undercover agents is now prohibited. Under some circumstances, the agent will not be engaging in an "interrogation" designed to elicit incriminating statements from a suspect upon whon suspicion has focused. See notes 105-06 supra and accompanying text. The suggestion in Escobedo that the right to counsel arises only after the suspect has been taken into custody may provide a further ground for sustaining legality of the activities of the agent. See notes 111-12 infra and accompanying text. Finally, it may be argued that where the words uttered to the agent are themselves elements of the offense, no right to counsel exists. See note 124 infra and accompanying text. 
other investigatory techniques previously thought to be acceptable. However, the Court has recently recognized that questioning of witnesses is "undoubtedly an essential tool in effective law enforcement." cordingly, it would seen that combining a reasonable determination of when the investigation has "focused" upon a particular defendant with the limitation that the questioning must be an "interrogation" designed to elicit incriminating statements would produce a rule that will not inhibit the police in making a general investigation of the facts and in questioning witnesses and possible suspects.

\section{Custody}

The defendant in Escobedo had been taken into formal police "custody" at the time of interrogation, and the opinion indicates that this miglit be a condition precedent to the operation of the right to counsel.111 If this is correct, then the effects of the expansion of the right to counsel begun in Escobedo will be considerably himited.

A strict view of "custody" would exclude from the scope of the requirement of counsel cases in which the accused surely needed the "guiding hand" of counsel. There is, to be sure, a considerable difference between statements unwittingly made to an undercover policeman and a formal interrogation at pohice headquarters. But what of the case where a pohice officer calls at the home of a suspect and proceeds to ask a series of questions, intended to elicit incriminating responses? Although the suspect, not under arrest, is technically free to leave, he may feel constrained. He may believe, rightly or wrongly, that any attempt to terminate the conversation will result in his arrest. It may be expected that the Court will not overlook these realities in favor of a formahistic rule based on a strict definition of "custody."112 While this factor may not be eliminated entirely, the Court will likely develop an expansive definition, perhaps terned "constructive custody," to include those circumstances where the suspect is in reality not free to terminate the questioning.

\section{Request for Counsel by the Accused}

It will be recalled that Danny Escobedo had specifically requested

110 Haynes v. Washington, 373 U.S. 503, 515 (1963).

111378 U.S. at 491 . The California Supreme Court was careful to note that the defendant was in custody at the time of the confession. People v. Dorado, 62 A. C. 350, 359, 42 Cal. Rptr. 169, 175 (1965). The Court stated elsewhere: "After custody the interrogation may become the critical stage in the establishment of the prosecution's case." Id. at 360, 42 Cal. Rptr. at 175. (Emphasis added.)

112 The Court did not define "custody," and may not have used it in a technical sense. See CAL. PEN. CODE $\S 835$ : "An arrest is made by an actual restraint of the person of the defendant, or by his submission to the custody of the officer." 
and been denied the opportunity to consult with his attorney. As a result, the Court did not find it necessary to consider the case in which the defendant made no such request prior to confessing. It might be argued that even though the interrogating officers failed to advise the defendant of his right to counsel and of his right to remain silent, in the absence of a request for counsel his constitutional rights are not infringed by interrogation in the absence of an attorney. The Supreme Court of Mllinois has so concluded. ${ }^{113}$ Since an individual may waive his constitutional rights, ${ }^{114}$ the failure of the accused to request counsel might be considered an implied waiver. Principles previously announced by the Court do not, however, permit such a narrow reading of Escobedo.

Traditionally, important constitutional rights have been protected against innocent and unintentional waiver. The Court indulges every reasonable presumption against waiver, ${ }^{115}$ refusing to "presume acquiescence in the loss of fundamental rights."116 Waiver has been defined by the Court as "an intentional relinquishment or abandonment of a known right or privilege."117 Only when the accused is aware of his right to counsel can he make a knowledgeable waiver. Indeed, the Court has held that, where the assistance of counsel is a constitutional requisite, the right to be furmished counsel does not depend on a request. ${ }^{118}$ The California Supreme Court concluded, in People v. Dorado, ${ }^{110}$ that the clear import of the decision in Escobedo was that counsel must be furnished under appropriate circumstances, regardless of the failure of the accused to demand counsel:

[T] he imposition of the requirement for the request would discriminate against the defendant who does not know his rights. The defendant who does not ask for counsel is the very defendant who most needs counsel. We cannot penalize a defendant who, not understanding his constitutional rights, does not make the formal request and by such failure demonstrates his helplessness. To require the request would be to favor the defendant whose sophistication or status had fortuitously prompted him to make it. ${ }^{120}$

113 People v. Hartgraves, Ill. App. 2d -, 202 N.E.2d 33 (1964). The reader should note that Escobedo was also an Illinois case.

114 Patton v. United States, 281 U.S. 276, 299 (1930).

115 Aetna Ins. Co. v. Kennedy, 301 U.S. 389, 393 (1937); Hodges v. Easton, 106 U.S. 408, 412 (1882).

116 Ohio Bell Tel. Co. v. Public Util. Comm'n, 301 U.S. 292, 307 (1937).

117 Jolnnson v. Zerbst, 304 U.S. 458, 464 (1938); waiver is defined as the "intentional or voluntary relinquishment of a known right." BLACK, LAW Dictronary (4th ed. 1951).

118 Carnley v. Cochran, 369 U.S. 506, 513 (1962). See also Uveges v. Pennsylvania, 335 U.S. 437, 441 (1948). Rice v. Olson, 324 U.S. 786, 788 (1945).

11062 A.C. 350,42 Cal. Rptr. 169 (1965).

$120 \mathrm{Id}$. at 363, 42 Cal. Rptr. at 176. Although only four justices voted for reversal, all but one member of the court agreed that the right to counsel did not depend on the presence 
It is, of course, true that the majority in Escobedo mentioned that the accused requested counsel. This was not intended to be a limitation on the scope of the right to counsel, but merely additional proof that the adversary system had begun to function:

When petitioner requested, and was denied, an opportunity to consult with his lawyer, the investigation had ceased to be a general investigation of "an unsolved crime." Petitioner had become the accused, and the purpose of the interrogation was to "get him" to confess his guilt despite his constitutional right not to do so..$^{121}$

Given the other elements of a "criminal prosecution," it is inconceivable that the United States Supreme Court would consider the failure to demand counsel controlling.

These, then, are the factors discussed in Escobedo which may operate to limit the scope of the right to counsel during interrogation. Considered together, they do not actually limit the right to counsel during interrogation, but merely define the existence of a "criminal prosecution" in its earliest stages. ${ }^{122}$ When attention lias become focused on a particular suspect who has been taken into "custody" and when the questioning beconies designed to elicit a confession, then the process lias shifted from investigatory to accusatory. The adversary systen lias begun to operate. A "criminal prosecution" has been set in motion, and the accused is the intended defendant. Under such circumstances, he may not be denied the assistance of counsel as guaranteed to him by the sixth amendment.

There is, however, at least one additional factor which, although not discussed in the cases as yet, may prove to be of significance. ${ }^{123}$

of a demand by the defendant. Justice Burke, joined by Justice Shauer, dissented only on the ground that the defendant had considerable experience with police practices and was evidently aware of his constitutional rights. Id. at 376-380, 42 Cal. Rptr. at 186-88 (dissenting opinion). Only Justice McComb found the absence of a demand for counsel controlling. Id. at 373-76, 42 Cal. Rptr. at 184-86 (dissenting opinion).

121378 U.S. at 485.

122 The sixth amendment refers to "all criminal prosecutions." See text accompanying note 3 supra.

123 Another issue left unresolved by the Court is whether the rights defined in these cases should be applied retroactively to those persons previously convicted under similar circumstances as Massiah and Escobedo. Obviously, to subscribe to the theory that constitutional rights, once discovered, must be applied retroactively, would involve, especially in the case of Escobedo, substantial administrative complexities, far beyond even those engendered by the retroactive application of Gideon v. Wainwright. Actually only four states were substantially effected by Gideon-Florida, Alabama, North and South Carolina -as the rest of the states already had some provision for the appointment of counsel.

On the other hand, failure to permit retroactive application would penalize those who might not otherwise have been convicted. A recent decision by the California Supreme Court, a companion case to Dorado, held that the rights set forth in Escobedo need not be applied retroactively. In re Lopez, 62 A.C. 380, 42 Cal. Rptr. 188 (1965). 


\section{E. Words Uttered by the Accused as Elements of the Crime Charged}

It is essential to distinguish between statements made by the accused while committing an actual offense and admissions made concerning a previous crime. Take, for example, the case of the narcotics investigator who poses as an addict in order to locate those engaging in the illegal sale of narcotics. In carrying out his role, many addicts make incriminating statements to him about past violations of law. In addition, a "pusher" orally offers to sell narcotics to him. May the officer testify as to these incidents, or do Escobedo and Massiah require exclusion of his testimony? Statements made by the addicts involve an admission of prior guilt-the traditional "confession." The "pusher's" offer consists of words which are themselves elements of the crime charged.

Even if the Court should conclude that there is a right to counsel where statements of past conduct are ehicited-disregarding, for the moment, the limitations discussed above-it would be appropriate to treat differently the case where the words uttered are elements of the crime charged. ${ }^{124}$ This would avoid the anomalous result of requiring the undercover agent to identify himself prior to deahing with the "pusher," a result which would seriously curtail the enforcement of narcotics laws.

\section{CONCLUSION}

Formulation of constitutional principles with regard to law enforcement requires that a balance be struck - a balance between effective enforcement of the law on one hand and protection of the individual from arbitrary or unfair pohice practices on the other. It is undoubtedly a virtue of our system that, if there is an imbalance, it exists in favor of the individual accused of crime. ${ }^{125}$ The State must observe certain evidentiary and procedural limitations in sustaining its burden of proving the defendant guilty. The police interrogation is an integral part of this process, and, as such, must be subject to appropriate supervision. One suspects that Escobedo was, in large part, an expression of the Court's dissatisfaction with the necessity of making a case-by-case determination of the voluntariness of the confession as a means of preventing police overreaching. If Escobedo is held to mean that the accused has an absolute right to counsel during a police interrogation, there would be a built-in check on the process of interrogation to insure that the requirements of the Constitution are strictly met.

The Court's determination that the right to counsel extends to interrogation will have a dramatic effect on law enforcement. The result could 
be the elimination of the confession as a significant factor in criminal convictions. ${ }^{126}$ Indeed, the Court appears to be willing to accept this development, as the majority opimion in Escobedo states:

We have learned the lesson of history, ancient and modern, that a system of criminal law enforcement which comes to depend on the confession will, in the long run, be less reliable and more subject to abuse than a system which depends on extrinsic evidence independently secured through skilful investigation. ${ }^{127}$

Richard Jaeger

126 See text accompanying note 88 supra.

127378 U.S. at $488-89$. 